\title{
1311 体積変化を考虑したヨ゙ム充填ポリマーブレンドの変形解析 Deformation analysis of rubber-filled polymer considering volume change behavior
}

\author{
○学 北村広之（山形大・院） \\ Hiroyuki KITAMURA \\ 正 黒田充紀（山形大・工） \\ Yamagata University, Yonezawa, 992-8510 Yamagata, Japan \\ Fax:0238-26-3205 E-mail:eem49285@dip.yz.yamagata-u.ac.jp
}

Key words: polymer blends; rubber-filled; volume change; tension and compression tests; finite element simulations.

\section{1. 緒言}

プラスチック材料は軽量且つ加工性，耐腐食性に優れ，日 用品から構造材料に至るまで，幅広い製品に利用されている. 現在は，ポリマーを単体で利用するのではなく，複合材料や 充填高分子など多成分, 多機能材料への移行が著しい. 用途 に適した材料特性を得る手法の一つに，プラスチック材料に 様々な異種材料を混合させるポリマーブレンドが挙げられ る。例えば，ゴム粒子のような低強度材料をプラスチック材 料内部に充填させることで，勒性の改善が図られる，材料の 組み合わせや体積分率等，最適な条件を求めるために，実験 からのアプローチが盛んに行なわれている．しかし，ブレン ドによって勒性が増すメカニズムは力学的には明確に解明 されていないこのメカニズムを詳細に解明することができ れば，目的の材料特性を持ったプラスチック材料を設計する ことが容易になるはず.

本研究では，ゴム粒子を内部に充填させたポリマーブレン ドの塑性変形挙動を精度よく再現するモデルを構築するこ とを目的とする．ポリマーブレンド内部に充填されたゴム粒 子は, 変形とともに母材から剥離し, ミクロボイドを形成さ せる.ゴム粒子を充填させたポリマーブレンドはボイド材と して取り扱うことができる. 鋳造材料等の数值解析に良く用 いられる Gurson モデル(1) とボイド成長による体積変化が降伏 条件に左右されない非関連流動則を応用して，モデル化を行 なう，数值解析に必要な材料パラメー夕を実験により同定す るが，解析対象とする材料モデルに近い状態で実験を行なう ことが重要である. 詳細な実験により材料パラメータを同定 した後, 提案モデルを用いて一軸引張試験のシミュレーショ ンを行ない, 力学挙動の再現を試みる.

\section{2. 構成式}

微小変形, 有限塑性を考慮し変形速度テンソルDを弾性部 分、塑性部分に分解し次のように定義する。

$$
\mathbf{D}=\mathbf{D}^{\mathrm{e}}+\mathbf{D}^{\mathrm{p}}
$$

弾性部分 $\mathbf{D}^{\mathbf{e}}$ にはフック則により恣式を用いる.

$$
\mathbf{D}^{\mathbf{e}}=\mathbf{C}^{-1} ; \boldsymbol{\sigma}
$$

降伏関数には，ポリマーブレンド内部のボイド成長と静水 応力依存性を考慮した次式(2)を用いる。

$$
\begin{array}{r}
\Phi_{\mathrm{Y}}=\frac{\tilde{\sigma}_{\mathrm{e}}^{2}}{\sigma_{\mathrm{F}}^{2}}+\frac{\mu_{\mathrm{Y}} \tilde{\sigma}_{\mathrm{m}}}{\sigma_{\mathrm{F}}}\left(2-\frac{\mu_{\mathrm{Y}} \tilde{\sigma}_{\mathrm{m}}}{\sigma_{\mathrm{F}}}\right)+2 q_{\mathrm{Y}} f \cosh \left(\frac{3 \tilde{\sigma}_{\mathrm{m}}}{2 \sigma_{\mathrm{F}}}\right) \\
-1-\left(q_{\mathrm{Y}} f\right)^{2}=0
\end{array}
$$

ここに, $\tilde{\boldsymbol{\sigma}}_{\mathrm{e}}=\sqrt{3 / 2 \tilde{\boldsymbol{\sigma}}^{\prime}: \tilde{\boldsymbol{\sigma}}^{\prime}}, \quad \tilde{\boldsymbol{\sigma}}=\boldsymbol{\sigma}-\boldsymbol{\alpha}, \boldsymbol{\sigma} は$ Cauchy 応力, $\boldsymbol{\alpha} は$ 背応力, ( )'は偏差成分, $\tilde{\sigma}_{m}=\tilde{\boldsymbol{\sigma}}: \mathbf{I} / 3, \sigma_{\mathrm{F}}$ は母材の流れ応力, $f$ はボイド含有体積率， $q_{\mathrm{Y}}$ は材料定数である.

変形速度テンソルの塑性部分 $\mathbf{D}^{\mathrm{P}}$ には次式の非関連流動則 を用いる。

$$
\mathbf{D}^{\mathrm{p}}=\dot{\Lambda} \mathbf{N}^{\mathrm{p}}, \quad \mathbf{N}^{\mathrm{p}} \equiv \frac{\partial \Phi_{\mathrm{p}}}{\partial \boldsymbol{\sigma}}
$$

ここに, $\boldsymbol{\Phi}_{\mathrm{p}}$ は塑性ポテンシャル関数であり, 次式を仮定する.

$$
\Phi_{\mathrm{P}}=\frac{\tilde{\sigma}_{\mathrm{e}}^{2}}{\sigma_{\mathrm{F}}^{2}}+\frac{\mu_{\mathrm{P}} \tilde{\sigma}_{\mathrm{m}}}{\sigma_{\mathrm{F}}}\left(2-\frac{\mu_{\mathrm{P}} \tilde{\sigma}_{\mathrm{m}}}{\sigma_{\mathrm{F}}}\right)+2 q_{\mathrm{P}} f \cosh \left(\frac{3 \tilde{\sigma}_{\mathrm{m}}}{2 \sigma_{\mathrm{F}}}\right)
$$

ここに， $\mu_{\mathrm{p}}$ と $q_{\mathrm{P}}$ はそれぞれ母材とボイドの体積増加を制御 するパラメータである.式(5)を式(4)に代入すると次のように なる.

$$
\mathbf{D}^{\mathrm{P}}=\dot{\Lambda}\left[\frac{3 \tilde{\boldsymbol{\sigma}}^{\prime}}{\sigma_{\mathrm{F}}^{2}}+\frac{q_{\mathrm{P}} f}{\sigma_{\mathrm{F}}} \sinh \left(\frac{3 \tilde{\sigma}_{\mathrm{m}}}{2 \sigma_{\mathrm{F}}}\right) \mathbf{I}+\frac{2}{3}\left(\frac{\mu_{\mathrm{P}}}{\sigma_{\mathrm{F}}}-\frac{\mu_{\mathrm{P}}^{2}}{\sigma_{\mathrm{F}}} \tilde{\sigma}_{\mathrm{m}}\right)\right]
$$

ボイドを含むマクロな材料の塑性仕事と，母材の塑性仕事の 等価性を仮定すると，亡が以下のように導かれる.

$$
\dot{\Lambda}=\frac{(1-f) \sigma_{\mathrm{F}} \dot{\bar{\varepsilon}} \overline{\mathrm{p}}}{\tilde{\boldsymbol{\sigma}}: \frac{\partial \Phi_{\mathrm{P}}}{\partial \boldsymbol{\sigma}}}
$$

ここで, $\dot{\bar{\varepsilon}}^{\mathrm{p}}$ は母材の相当塑性ひずみ速度を示し, 次のような ベき乗関係にある。

$$
\dot{\bar{\varepsilon}}^{\mathrm{p}}=\dot{\varepsilon}_{0}\left(\frac{\sigma_{\mathrm{F}}}{r \sigma_{0}+(1-r) \sigma_{0} \bar{g}\left(\bar{\varepsilon}^{\mathrm{p}}\right)}\right)^{1 / m}
$$

ここに， $\dot{\varepsilon}_{0}$ は基準ひずみ速度， $\sigma_{0}$ は初期降伏応力， $m$ はひ ずみ速度敏感性指数, $\bar{g}\left(\bar{\varepsilon}^{\mathrm{p}}\right)$ はマク口な静水応力を考慮した 母材の硬化関数, $r$ は移動硬化係数である.

塑性体積ひずみ速度 $\dot{\varepsilon}_{\mathrm{V}}^{\mathrm{p}}$ は式(6)から次式で与えられる。

$$
\begin{aligned}
& \dot{\varepsilon}_{\mathrm{V}}^{\mathrm{p}} \equiv \mathbf{D}^{\mathrm{P}}: \mathbf{I}=\dot{\Lambda}\left[\frac{3 q_{\mathrm{P}} f}{\sigma_{\mathrm{F}}} \sinh \left(\frac{3 \tilde{\sigma}_{\mathrm{m}}}{2 \sigma_{\mathrm{F}}}\right)\right]+\dot{\Lambda}\left[2\left(\frac{\mu_{\mathrm{P}}}{\sigma_{\mathrm{F}}}-\frac{\mu_{\mathrm{P}}^{2}}{\sigma_{\mathrm{F}}^{2}} \tilde{\sigma}_{\mathrm{m}}\right)\right] \\
& \equiv \dot{\varepsilon}_{\mathrm{V}(\mathrm{f})}^{\mathrm{p}}+\dot{\varepsilon}_{\mathrm{V}(\mathrm{M})}^{\mathrm{p}}
\end{aligned}
$$

ここで, 右辺第 1 項がボイド，第 2 項が母材の塑性体積ひず み速度となり，添字をそれぞれ $\mathrm{f} ， \mathrm{M}$ として示す．ボイド含 有体積率の発展式は,

$$
\dot{f}=(1-f) \dot{\varepsilon}_{\mathrm{V}}^{\mathrm{p}}-\dot{\varepsilon}_{\mathrm{V}(\mathrm{M})}^{\mathrm{p}}
$$

で与えられる.

背応力の発展式には次式を仮定する.

$$
\stackrel{\circ}{\boldsymbol{\alpha}}=b \dot{\Lambda} \tilde{\boldsymbol{\sigma}}
$$

ここに，係数 $b$ は一定ひずみ速度の比例負荷下で, 完全等方 硬化則と完全移動硬化則の単軸引張解析态答が一致すると いう条件から決定する。

\section{3. 実䀫}

\section{3-1 試供材料}

解析対象とするポリマーブレンドは, 母材にポリカーボネ イト（PC）, 内部に充填するゴム粒子に SEBS 水添スチレン 系熱可塑性エラストマーを用いる. PC と SEBS を混練したぺ レットから射出成形のみで試料を作製すると, 射出方向の内 部状態は, Fig. 1(a)のようにゴム粒子が配向を起こし, 流動 方向に沿った形で並んでしまう。これでは変形とともに, 内 部に球状ボイドを生成させることは難しい，内部に球状ボイ ドを生成させるために，まず材料を射出成形機を用いて角柱 に加エした後, 温間プレス加工を施寸ことで, ゴム粒子を球 状に充填させることが可能となった（Fig. 1(b)，(c)）。プレ 
ス条件は, 加熱温度 $270^{\circ} \mathrm{C}$, 保持時間 20 分とした. 本研究で は，この方法で作成したポリマーブレンドを解析対象として 扱い，材料パラメータを同定するための実験に使用する。 た，母材となる PC も同様の方法で試料を作製し，実験を行 なう。

\section{3-2 引張・圧縮試睌}

降伏現象における静水応力依存性は，係数 $\mu_{Y}{ }^{(3)}$ によって規 定される. $\mu_{\mathrm{Y}}$ は引張降伏応力 $\sigma_{\mathrm{T}}$ 上圧縮応力值 $\left|\sigma_{\mathrm{C}}\right|$ から次式 のようになる( ${ }^{(3)}$.

$$
\mu_{\mathrm{Y}}=3\left(\frac{\left|\sigma_{\mathrm{C}}\right|-\sigma_{\mathrm{T}}}{\left|\sigma_{\mathrm{C}}\right|+\sigma_{\mathrm{T}}}\right)
$$

引張・圧縮降伏応力を求めるために，20vol\%の SEBS を混合 したボリマーブレンド（PC-20vol\%SEBS）に対して引張・圧 縮試験を行った。引張試験では, 平行部 $70 \mathrm{~mm}$, 板厚 $2 \mathrm{~mm}$, 板幅 $6 \mathrm{~mm}$ のダンベル試験片を, 圧縮試験では, 標点間距離 $10 \mathrm{~mm}$, 板厚 $5 \mathrm{~mm}$, 板幅 $9 \mathrm{~mm}$ の角柱試験片を使用する. それ ぞれひずみ速度がー一定になるように試験を行なう。但し，こ こでのひずみ速度とは, 試験速度考標点間距離で除した公称 ひずみ速度とする，また，圧縮する際には試験片の接触面に 二硫化モリブデンを塗布し, 摩擦による拘束を軽減させる. 測定結果を Fig. 2 に示す. 射出成形のみの場合 (Compression 2）と比較すると，降伏応力が約 $10 \%$ 低下していることがわ かる.これは, 射出成形後のプレス加工により, 試料の配向

（Fig. 1(a)）が緩和された影響と考えられる. Fig. 2 から PC-20vol\%SEBS について $\mu_{\mathrm{Y}}=0.089$ \%値を得た。しかし, 引 張におけるボイドの成長収縮挙動を考慮すると， $\mu_{\mathrm{Y}}=0$ と仮 定 (Tension analysis, Compression analysis) しても実験結果を 再現できることがわかった。

\section{3-2 体積变化測定}

母材となる $\mathrm{PC}$ の体積変化挙動は $\mu_{\mathrm{p}}$ に, ボイドの成長によ る体積変化は $q_{\mathrm{P}}$ によってそれぞれ支配される，引張および， 圧縮变形に伴う塑性体積ひずみを質量密度法により測定し た。結果をFig. 3 に示す，PCに関しては，引張，圧縮とも にほとんど体積変化を起こさない傾向にある。 PC-20vol\%SEBS の場合, 引張において体積が膨張する. 引張 における体積変化挙動を再現するために， $q_{\mathrm{P}}$ に対して次のよ うな関数を用いる.

$$
q_{\mathrm{P}}=q_{\mathrm{P} 0} \exp \left(-c_{\mathrm{P}} \bar{\varepsilon}^{\mathrm{p}}\right)
$$

Fig. 3 中に示すように $q_{\mathrm{P} 0}=1.3, c_{\mathrm{P}}=5.0$ を用いる (Computation)ことにより, ポリマーブレンドの体積変化を 再現することができる．圧縮においては，わずかながら体積 が減少する傾向がある。これは，圧縮によってボイドの収縮 が起こり，それがマクロな体積減少という形で現れたと考え ることができる。压縮に扔ける解析結果 (Computation 2) と 比較すると，ひずみの上昇に伴い解析值が実験值を上回るこ とがわかる、これは，圧縮によるボイドの収縮が SEBS の残 留物等により阻害されているため, 実際の体積変化は小さく なっていると考えられる。

\section{4. 今後の展望}

前節で，解析対象とする試料および，材料パラメータ0同 定のための実験方法について検討を行った.

静水灾力依存性に関しては，母材となるPCについても詳 細に実験を行ない，SEBS をブレンドしたことによる影響を 確認する必要がある。

PC-20vol\%SEBS の体積変化測定の結果から,引張により体 積は増加し，圧縮では減少することがわかった，今後は各ひ ずみ值に対する実験数を増やし，体積変化挙動の詳細なモデ ル化を目指す。さらに，同じ試料を用いて引張・圧縮反転試 験を行ない，移動硬化係数を同定寸る，実験から必要なパラ
メータを得ることができた後，引張試験解析を行ない，提案 モデルを検討する。

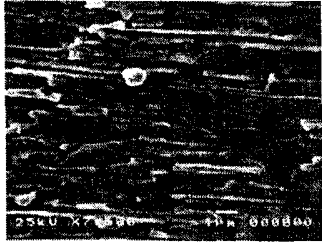

(a)

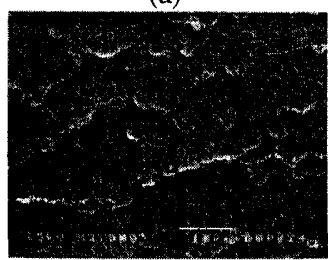

(b)

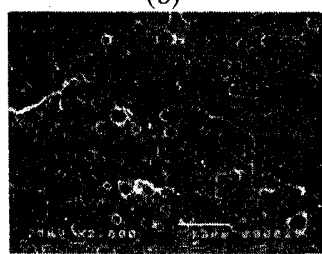

(c)

Fig. 1 SEM micrographs of specimen: (a) surface (injection molding); (b) surface (injection molding and press work); (c) cross section (injection molding and press work)

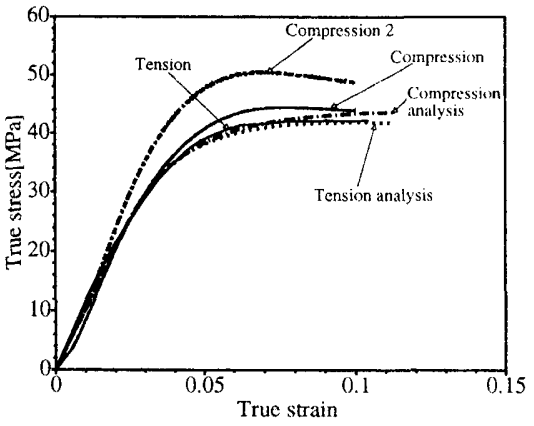

Fig. 2 Uniaxial tension and compression test results for PC-20vol\%SEBS blend.

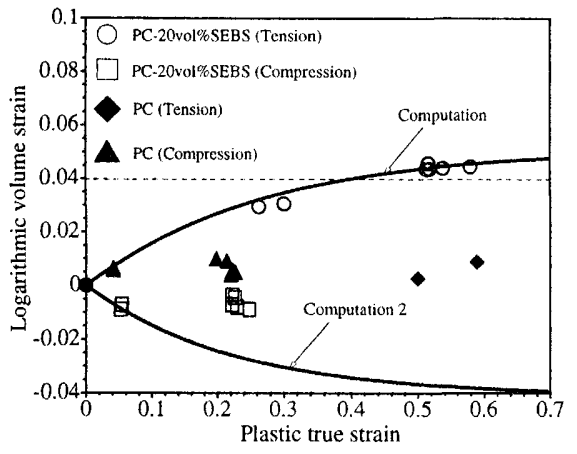

Fig. 3 Volume change of PC and PC-20vol\%SEBS blend.

謝辞 : 本研究を進めるにあたり，本学機能高分子工学科石川 優教授に多大なご協力を頂きました。ここに記して深謝いた します。

\section{参考文献}

(1) Gurson, A.L., J. Eng. Mat. Tech. 99(1977), 2-15.

(2) Lazzeri, A., Bucknall, C.B.,J.MatSci.28(1993), 6799-6808.

(3) 黒田, 築山, 石川, 日本機械学会 2005 年度年次大会講演 論文集(2005) in press. 